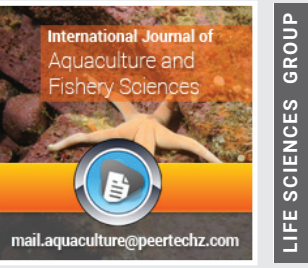

\title{
Skin coloration and habitat preference of the freshwater Anguilla eels
}

\author{
Hsiang-Yi Hsu, Yen-Ting Lin, Yi-Cheng Huang* and Yu-San \\ Han*
}

Institute of Fisheries Science, College of Life Science, National Taiwan University, Taipei 10617, Taiwan

Received: 15 April, 2020

Accepted: 01 September, 2020

Published: 03 September, 2020

*Corresponding authors: Yi-Cheng Huang, Institute of Fisheries Science, College of Life Science, National Taiwan University, Taipei 10617, Taiwan,

E-mail: ethan831231@gmail.com

Yu-San Han, Institute of Fisheries Science, College of Life Science, National Taiwan University, Taipei 10617, Taiwan, E-mail: yshan@ntu.edu.tw

Keywords: Skin coloration; Habitat preference; Freshwater eels; Adaptation

https://www.peertechz.com

Check for updates

\section{Abstract}

The genus Anguilla comprises 16 species and three subspecies of freshwater eels, which can be further divided into marbled and plain eels in terms of skin coloration on their backs. Owing to the overlap of geographical distributions between most marbled and plain eels in tropical/subtropical regions, the co-existence of marbled and plain eels in the same river is common. To understand the correlation between eel skin color and its habitat preference in the river, the distribution patterns of all anguillid eels were collected and analyzed. Results showed that all marbled eels distribute in tropical/subtropical areas and preferred the middle/upper reaches. The plain eels distributed both in temporal and tropical/subtropical areas, and preferred to inhabit the middle/lower reaches and estuaries. Plain skin coloration may help them easily remain hidden in a sandy and muddy environment, which is common in estuaries and lower reaches of rivers in tropical/subtropical areas, while mottled skin coloration more easily blends in with substrates such as cobble, gravel, and fallen leaves which are commonly found in the upper reaches of rivers in the tropical/subtropical areas. The different habitat preference between marbled and plain eels in the tropical/subtropical areas are likely a result of adaptive evolution to avoid potential interspecific competition, and this finding is meaningful for developing applicable management plans for eels.

\section{Introduction}

For centuries, the life history of freshwater eels (genus Anguilla) was a mystery to biologists. Freshwater eels are typical catadromous fish; they spend most of their lifetime in freshwater rivers and estuaries before finally migrating to their spawning grounds in the ocean for reproduction [1]. In total, there are 16 species and three subspecies of freshwater eels identified in the world [2-4], which can be categorized into two groups based on body coloration: mottled skin and uniformly-colored skin, called "marbled eels" and "plain eels" [5]. Marbled eels are typically distributed mainly in tropical and subtropical regions, whereas plain eels are distributed over tropical, subtropical, and temperate regions [1]. Marbled and plain eels coexist in some rivers in tropical and subtropical regions, where they may share the same niches, and forage for the same prey, thereby causing possible interspecific competition [4]. Thus, under selection pressure, eels may evolve some morphological and physiological characters to reduce interspecific competition and maximize their sustainability.
In recent years, several studies have been conducted on habitat choices of eels, and these revealed that they can be influenced by extrinsic environmental factors, such as salinity, water temperature, river size, and carrying capacity [6-8]. Other than these factors, the habitat preference of the eel in the river appears to be species-specific. For instance, the giant mottled eel (A. marmorata, a marbled eel) was inclined to inhabit the middle and upper reaches of rivers, but the Japanese eel (A. japonica, a plain eel) tended to dwell in the estuaries and lower reaches of rivers, as determined by analysis of trace elements ( $\mathrm{Sr} / \mathrm{Ca}$ ratios) in the otoliths taken from wild-captured eels in the same river $[6,7,9]$, or by field investigation [10]. Body coloration of animals facilitates a number of important physiological and behavioral functions, including thermoregulation, mate attraction, rival deterrence, and predator avoidance [11]. To better understand the life history strategy of the anguillid eels, especially the role of eel skin color on its habitat preference in the river, data were collected and analyzed to summarize the phylogenetic relationship, geographical distribution and habitat preference between marbled and plain eels. 


\section{Materials and methods}

\section{Body coloration, biogeographic distribution and habitat preference of Anguilla eels}

The habitats of freshwater eels in the river can be classified into the upper reaches/mountain stream, middle reaches, and lower reaches/estuaries according to the hydrological conditions and the distance from the estuary. We searched online reference banks of Web of Science, Library of Congress, and Google Scholar till December 2019 to acquire habitat distribution information of anguillid eels. The search used combined key words like Anguilla, habitat, and distribution. We also searched specialist books and conference proceedings we had on hand regardless of the language. All acquired papers studying the biogeographic distribution and habitat preference of Anguilla eels were screened by manpower.

\section{Evolutionary relationships of Anguilla eels}

The evolutionary history of 19 Anguilla eels was inferred using the Neighbor-Joining method (Saitou \& Nei, 1987) based on the complete mitochondrial genome (Table 1). The marine eel Moringua edwardsi was used as the outgroup species. The optimal tree with the sum of branch length $=0.66905714$ was shown. The percentage of replicate trees in which the associated taxa clustered together in the bootstrap test (1000 replicates) was shown next to the branches [12]. The evolutionary distances were computed using the Maximum Composite Likelihood method [13] in the units of the number of base substitutions per site. This analysis involved 20 nucleotide sequences. Codon positions included were $1 \mathrm{st}+2 \mathrm{nd}+3 \mathrm{rd}+$ Noncoding. All positions

Table 1: Accession numbers of 19 Anguilla eels and one outgroup marine eel.

\begin{tabular}{|c|c|}
\hline Species & Accession No. \\
\hline Anguilla japonica & NC_002707.2 \\
\hline Anguilla anguilla & NC_006531.1 \\
\hline Anguilla australis australis & NC_006532.1 \\
\hline Anguilla australis schmidti & NC_006533.1 \\
\hline Anguilla bicolor bicolor & NC_006534.1 \\
\hline Anguilla bicolor pacifica & NC_006535.3 \\
\hline Anguilla malgumora & NC_006536.1 \\
\hline Anguilla celebesensis & NC_006537.1 \\
\hline Anguilla dieffenbachii & NC_006538.1 \\
\hline Anguilla interioris & NC_006539.1 \\
\hline Anguilla marmorata & NC_006540.1 \\
\hline Anguilla megastoma & NC_006541.1 \\
\hline Anguilla mossambica & NC_006542.1 \\
\hline Anguilla bengalensis labiata & NC_006543.1 \\
\hline Anguilla bengalensis nebulosa & NC_006544.1 \\
\hline Anguilla obscura & NC_006545.1 \\
\hline Anguilla reinhardtii & NC_006546.1 \\
\hline Anguilla rostrata & NC_006547.2 \\
\hline Anguilla luzonensis & NC_011575.1 \\
\hline Moringua edwardsi & AP_010840.1 \\
\hline
\end{tabular}

containing gaps and missing data were eliminated (complete deletion option). There were a total of 16350 positions in the final dataset. Evolutionary analyses were conducted by MEGA $\mathrm{X}[14]$.

\section{Results}

\section{Relationship between body coloration and habitat usage of freshwater eels}

With reference to previous studies, A. marmorata, A. luzonensis, A. bengalensis bengalensis, $A$. bengalensis labiata, $A$. interioris, $A$. celebesensis, A. megastoma, and A. reinhardtii were classified as marbled eels, and all other 11 species/subspecies were classified as plain eels. The worldwide geographical distribution of marbled eels and plain eels showed that the marbled eels often overlapped with those of plain eels (Figure 1) in tropical/subtropical areas.

Body coloration, geographical distribution, and habitat distribution data of all eel species were listed (Table 2). A. marmorata was inclined to inhabit the upper reaches of rivers, while A. japonica, A. bicolor bicolor, and A. bicolor pacifica (all plain eels) tended to inhabit the lower reaches (brackish/sea waters) $[6,7,10,15,16]$. A. bengalensis bengalensis, the Indian mottled eel, was reported to reside from the upper- to midstream areas with cooler water temperatures and higher elevation $[8,17]$. The African mottled eel, A. bengalensis labiata, mainly inhabited areas far inland by surmounting formidable barriers in their upstream migration $[18,19]$. The Luzon mottled eel, $A$. luzonensis, mainly found in Luzon Island of the Philippines (Han et al. 2016), inhabited the upper reaches and pure freshwater areas suitable for its growth [20]. A. interioris, the long-finned marbled eel, was mainly found in the freshwater of highlands in New Guinea [21], but the glass eels of A. interioris were ever detected at Java Island and southern Mindanao Island [22,23]. Another marbled eel, A. celebesensis, was reported to reside from the upper reaches of rivers in Sulawesi Island [24,25]. In addition to the Sulawesi Island, the glass eels of A. celebesensis were ever detected at Philippines coasts [26]. A. megastoma, the Pacific long-finned marbled eel, was found only in the middle or upper reaches near the headwaters of freshwater rivers $[27,28]$. The Australian long-finned marbled eel, A. reinhardtii, was one of main eel species at East Coast of Australia [29], and commonly found in many freshwater areas, including the upper reaches of rivers, dams, and lakes [30].

A. mossambica, a species of plain eel, is an inter-habitat migrant, moving between freshwater and seawater habitats, as indicated by microchemical analysis of their otoliths [31]. In another study, A. mossambica was found to inhabit coastal and estuarine areas without migration upstream into inland freshwater areas [32]. A. malgumora (A. borneensis), also called Indonesian longfinned eel, was a common plain eel inhabiting the lower and middle reaches of rivers in Borneo and Sulawesi Island of Indonesia and Sabah of Malaysia [33,34]. A. obscura, the Pacific short-finned plain eel, was distributed primarily over the lower reaches of rivers and coastal lagoons at western South Pacific, including Papua New Guinea, Fiji, and French Polynesia $[27,35,36]$. The other two short-finned plain eels, 
(a)

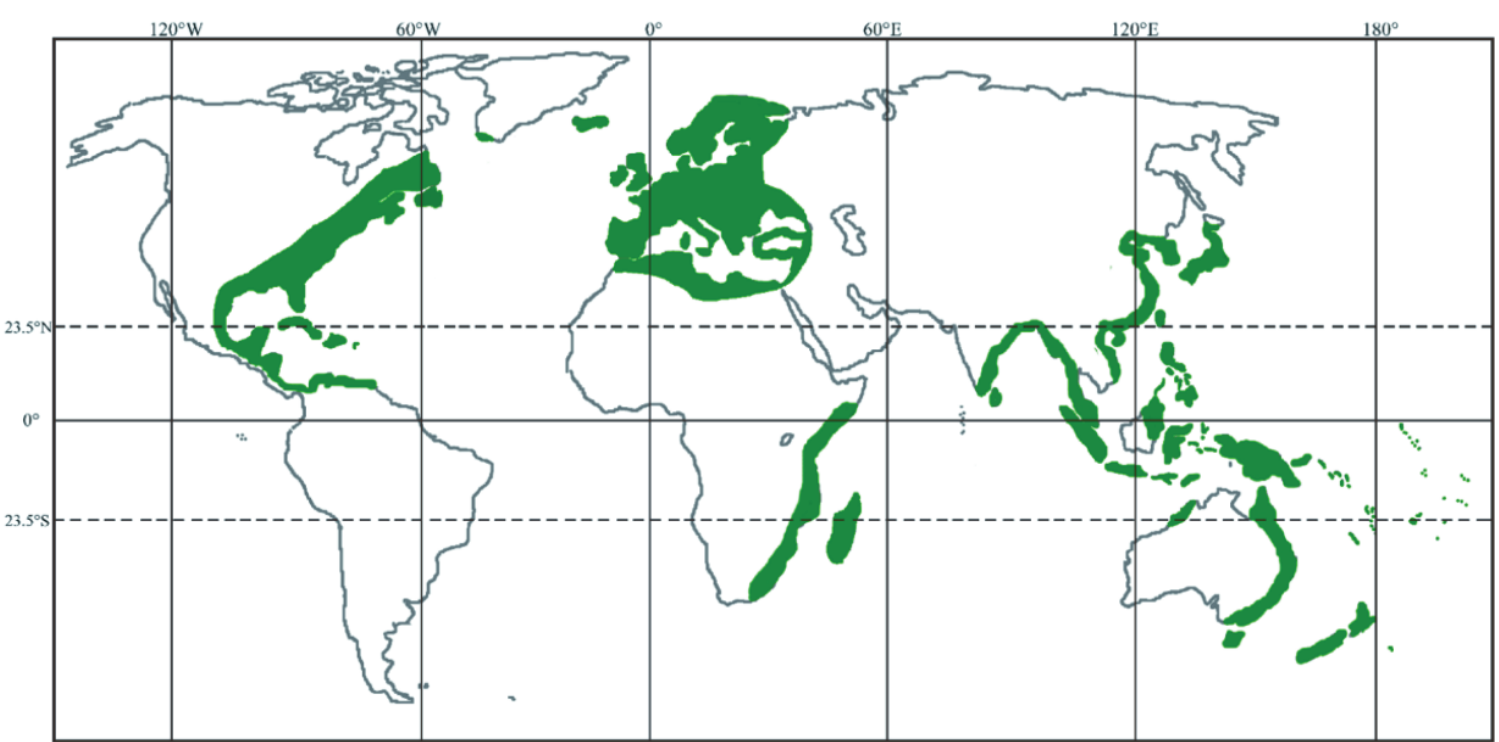

(b)

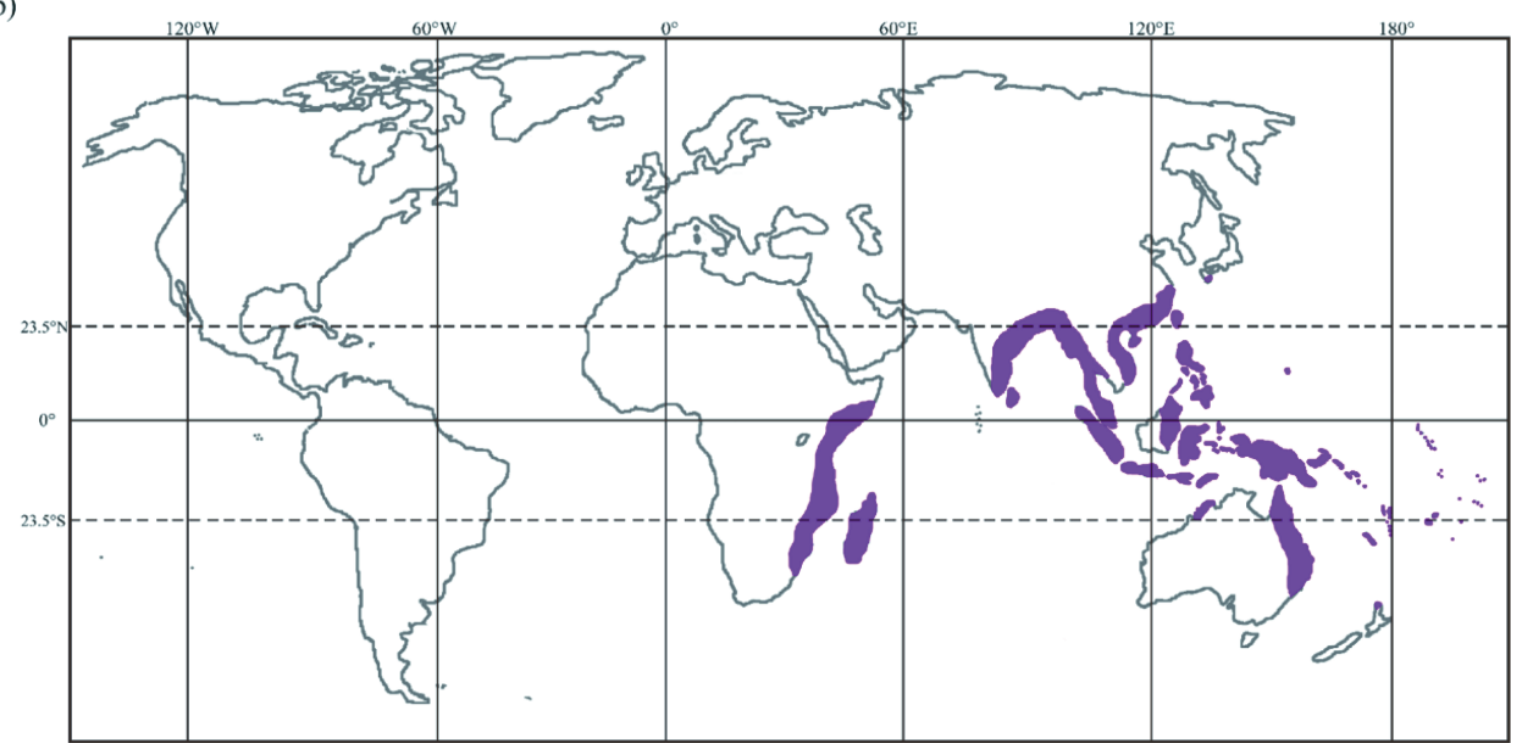

Figure 1: Worldwide biogeographical distribution of freshwater eels (a) Plain-colored eels were mainly distributed in temperate, subtropical, and tropical areas (green). (b) Marbled eels were distributed in subtropical and tropical areas (purple). This figure was redrawn by the authors using Adobe Illustrator CS6 (Adobe Systems Incorporated, USA) with reference to a world map (WRLD-EPS-01-0006), which was downloaded from the Free Vector Maps website (https://www.freevectormaps.com/).

A. australis australis and A. australis schmidtii, were distributed mainly over eastern Australia and New Zealand, respectively, where their predominant habitats were lower reaches of rivers and estuaries $[8,20,37]$. In New Zealand, A. dieffenbachi (a plain eel) was commonly found in pure freshwater near the middle and lower reaches of rivers. Most populations of $A$. rostrata and $A$. anguilla were found in estuaries, lower reaches of rivers, and lowland lakes, where they usually completed their growth phase. However, they also appeared in the middle and upper reaches of rivers [38-40].

\section{Phylogeny analysis of Anguilla eels in relationship to skin color and habitat type}

The phylogenetic relationships, skin color and temporal/ tropical characters of 19 Anguilla eels were constructed in Figure 2. Generally, eels with closer phylogenetic relationships possess similar morphological and distribution characteristics. Most marbled eels shared a close phylogenetic relationship, and, likewise, most of the plain eels shared a close phylogenetic relationship. All marbled eels distribute in tropical/subtropical areas, and all temporal eels have plain skin colors.

\section{Discussion}

Teleost fish develop at least six classes of pigment cells (chromatophores) leading to a fascinating diversity of colors [41]. anguillid eels are characterized with a dark or marbled back produced by black/brown melanophores and yellow/ orange xanthophores at the inner and outer boundaries of the dermis [42]. The mechanism in controlling skin color pattern of the anguillid eels may be related to Agouti signaling protein [41]. Some animals adapt to their environment through body coloration. For example, chameleons maintained crypsis 
and communicated by changing their body coloration [43]. Cephalopods, such as octopuses, can rapidly change their body coloration to mimic visual characteristics of the background [44]. Another method of camouflage, known as countershading, has been reported in fish species $[11,45]$. Some body coloration of fish, including eels, is darker on the upper side and brighter on the underside. When seen from the underside, the brighter ventral body would blend in with the light background. In contrast, when seen from the top in daylight, the darker dorsal surface would blend in with the dark background of the deep water or substrate below [46]. Freshwater eels may also have evolved different body colorations (marbled and plain) in order to blend in with their habitat.

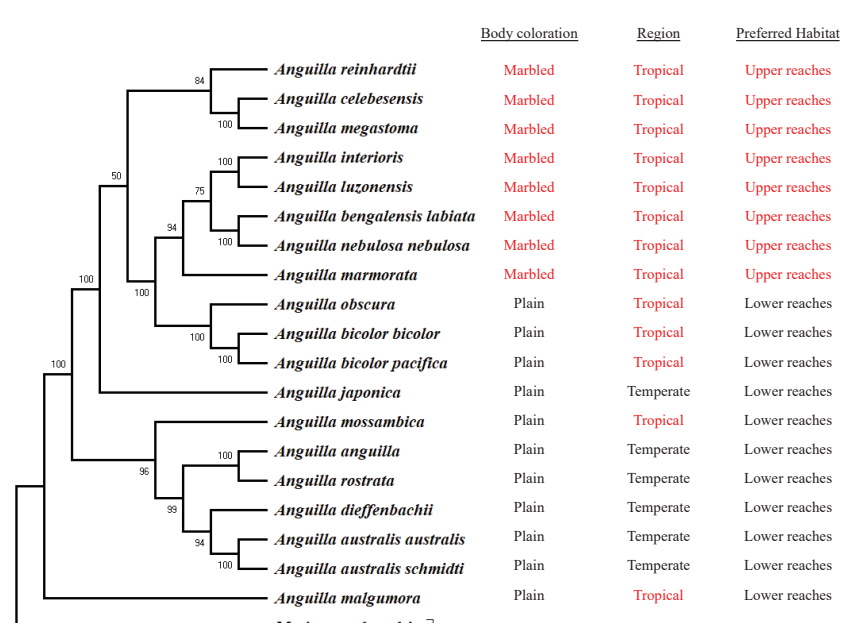

The comprehensive analysis of this study indicated that, in tropical/subtropical areas where marbled and plain eels coexist, marbled eels tended to inhabit the middle to upper reaches of rivers while plain eels prefer the habitats located from the middle reaches to estuaries (Table 2). In a typical river system of tropical/subtropical areas, the substrates found in upper reaches are primarily boulders, bedrock, cobble, and gravel, which are quite different from the substrates of the lower reaches, which are more sandy and muddy because rivers deposit eroded materials carried from the upper reaches [47]. The countershading of plain eels may help them remain hidden in a sandy and muddy environment, allowing them to avoid being detected by predators/prey. On the other hand, marbled eels can blend in with substrates such as cobble, gravel, and fallen leaves in the upper reaches.

In rivers located in tropical/subtropical areas, they were usually cohabited by at least one dominant plain eel and one dominant marbled eel. For example, A. japonica (plain) and A. marmorata (marbled) were dominant and coexisted in the rivers of Taiwan [3,10]; A. bicolor pacifica (plain) and A. luzonensis (marbled) were dominant and coexisted in rivers on East Luzon Island [48]; A. australis australis (plain) and A. reinhardtii (marbled) were dominant and coexisted in rivers of eastern Australia [29]; A. mossambica (plain) and A. marmorata (marbled) were dominant and coexisted in rivers of Mozambique [31]; and A. bicolor bicolor (plain) and A. bengalensis bengalensis (marbled) were dominant and coexisted in rivers of Peninsular Malaysia and India [4,17]; and A. marmorata (marbled) and A. bicolor pacifica (plain) were dominant and coexisted in rivers of Vietnam [16]. In addition, A. obscura (plain) using the lower reaches of rivers, A. marmorata (marbled) using the middle

Figure 2: Phylogenetic tree and skin color of the genus Anguilla.

Table 2: Body coloration, biogeographical distribution and preferred habitats of Anguilla spp.

\begin{tabular}{|c|c|c|c|c|}
\hline Species & Body coloration & Main geographical distribution & Preferred habitat & Main References \\
\hline A. marmorata & Marbled & $\begin{array}{l}\text { Taiwan, Indonesia, Philippines, East Africa, French Polynesia, Malaysia, } \\
\text { Vietnam }\end{array}$ & Upper reaches & {$[6,7,10,15,16,31]$} \\
\hline A. bengalensis bengalensis & Marbled & India, Peninsular Malaysia & Upper reaches & {$[8,17]$} \\
\hline A. bengalensis labiata & Marbled & East Africa, Kenya & Upper reaches & {$[18,19]$} \\
\hline A. luzonensis & Marbled & Luzon Island (Philippines) & Upper reaches & {$[20,48]$} \\
\hline A. interioris & Marbled & $\begin{array}{c}\text { Papua New Guinea, Mindanao Island (Philippines), Java \& Sulawesi Island } \\
\text { (Indonesia) }\end{array}$ & Upper reaches & [21-24] \\
\hline A. celebesensis & Marbled & Sulawesi Island (Indonesia), Philippines & Upper reaches & {$[24-26]$} \\
\hline A. megastoma & Marbled & Solomon Islands, Fiji, New Caledonia, French Polynesia & Upper reaches & {$[27,28]$} \\
\hline A. reinhardtii & Marbled & Eastern Australia, Northern New Zealand & Upper reaches & {$[29,30]$} \\
\hline A. malgumora & Plain & Borneo and Sulawesi (Indonesia), Sabah of Malaysia & Lower reaches & {$[33,34]$} \\
\hline A. mossambica & Plain & East Africa, Madagascar, South Africa & Lower reaches & {$[31,32]$} \\
\hline A. obscura & Plain & Papua New Guinea, Fiji, French Polynesia (western South Pacific) & Lower reaches & {$[27,35,36]$} \\
\hline A. bicolor bicolor & Plain & India, Java Island, East Africa, Peninsular Malaysia & Lower reaches & {$[7,8,15]$} \\
\hline A. bicolor pacifica & Plain & Philippines, Sulawesi (Indonesia), Vietnam & Lower reaches & {$[7,16,22]$} \\
\hline A. australis australis & Plain & Eastern Australia, New Zealand & Lower reaches & {$[37,38,20]$} \\
\hline A. australis schmidtii & Plain & New Zealand & Lower reaches & {$[20,37,38]$} \\
\hline A. dieffenbachi & Plain & New Zealand & Lower reaches & [38] \\
\hline A. rostrata & Plain & Eastern North and Central America & Lower reaches & {$[39]$} \\
\hline A. anguilla & Plain & Europe, North Africa & Lower reaches & {$[28]$} \\
\hline A. japonica & Plain & Taiwan, China, Korea, Japan & Lower reaches & {$[6,10,32]$} \\
\hline
\end{tabular}

Citation: Hsu HY, Lin YT, Huang YC, Han YS (2020) Skin coloration and habitat preference of the freshwater Anguilla eels. Int J Aquac Fish Sci 6(3): 096-101. 
reaches, and A. megastoma (marbled) using the upper reaches in rivers of French Polynesia [27]. The potential for interspecific competition between eel species in these rivers could be effectively reduced by this habitat partitioning strategy. Interestingly, recent study indicated that hybridization and gene exchange are pervasive in tropical eel species, but that these species have nevertheless remained distinct entities for several million years. Cytonuclear incompatibilities and hybrid breakdown may be powerful mechanisms which help maintaining species boundaries [49].

Phylogenetic tree revealed that most marbled eels shared a close phylogenetic relationship, and, likewise, most of the plain eels shared a close phylogenetic relationship (Figure 2). The eels with closer phylogenetic relationships possessed similar skin coloration, which probably results from their long-term adaptive evolution. It is also worth noting that only plain eels inhabited the temperate areas. In temperate areas, the upper reaches of rivers are usually characterized by low primary productivity and low temperature, thus lacking suitable habitats for eels. Subsequently, eels usually inhabit the estuaries and lower reaches of rivers in temperate areas. Marbled eels which have evolved to adapt tropical/subtropical areas were thus rare in temperate area.

Previous study indicated that American eels could be distributed over the middle reaches of rivers in temperate areas [39]. A recent study has also revealed that the giant mottled eel is distributed throughout estuaries and the middle and upper reaches of some short tropical rivers [50-54]. These large-scale habitat distributions may result from a lack of interspecific competition. That is, eels may be able to expand their habitat range to some extent if no competitive species exist. Even so, the habitat partitioning between plain and marbled eels in the same river is a common phenomenon in almost all geographical areas.

The differences in body coloration between marbled eels and plain eels are likely a result of adaptive evolution which may help to reduce potential interspecific competition when they coexist in the tropical/subtropical rivers. This finding is important for developing applicable management plans for eels with different skin color types, with lower reach/estuary for protecting plain eels and middle/upper reaches for conserving marbled eel species.

\section{Acknowledgments}

The authors thank the Ministry of Science and Technology, Executive Yuan, Taiwan (NSC 102-2628-B-002 -023 -MY3, MOST 105-2313-B-002-030, MOST 106-2313-B-002 -036 $-\mathrm{MY} 3)$, and the Council of Agriculture, Executive Yuan, Taiwan (106AS-11.3.4-FA-F1) for funding this project.

\section{Author contributions}

Hsiang-Yi Hsu and Yen-Ting Lin mainly conducted the experiments, analyzed the results, and wrote the manuscript. Yi-Cheng Huang and Yu-San Han designed and supervised the experiments and participated in manuscript writing and interpretation of results.

\section{References}

1. Tesch FW (2003) The eel. Blackwell Science, Oxford, U.K.

2. Ege V (1939) A revision of the genus Anguilla Shaw, a systematic, phylogenetic and geographical study. Dana Rep 16:1-256. Link: https://bit.ly/2EX3oKm

3. Watanabe S (2003) Taxonomy of the freshwater eels, genus Anguilla Schrank, 1798. In: Aida K, Tsukamoto K, Yamauchi K (eds) Eel Biology. Springer Japan, Tokyo 3-18. Link: https://bit.ly/32VoJft

4. Arai T (2016) Taxonomy and Distribution. In: Arai T (ed) Biology and Ecology of Anguillid Eels CRC Press 1-20. Link: https://bit.ly/3lHk3IU

5. Smith DG (1999) Anguillidae. Freshwater eels. In: Carpenter KE, Niem VH (eds) FAO species identification guide for fishery purposes. The living marine resources of the Western Central Pacific. Volume 3. Batoid fishes, chimaeras and bony fishes part 1. FAO, Rome 1630-1636.

6. Shiao JC, lizuka Y, Chang CW, Tzeng WN (2003) Disparities in habitat use and migratory behavior between tropical eel Anguilla marmorata and temperate eel A. japonica in four Taiwanese rivers. Mar Ecol Prog Ser 261: 233-242. Link: https://bit.ly/2YZ5IY8

7. Briones AA, Yambot AV, Shiao JC, lizuka Y, Tzeng WN (2007) Migratory pattern and habitat use of tropical eels Anguilla spp. (Teleostei: Anguilliformes: Anguillidae) in the Philippines, as revealed by otolith microchemistry. Raff Bull of Zool 14: 141-149. Link: https://bit.ly/3566PcJ

8. Arai T, Abdul Kadir SR (2017) Diversity, distribution and different habitat use among the tropical freshwater eels of genus Anguilla. Sci Rep 7: 7593. Link: https://go.nature.com/3hV8eGn

9. Tzeng WN, Shiao JC, lizuka Y (2002) Use of otolith Sr:Ca ratios to study the riverine migratory behaviors of Japanese eel Anguilla japonica. Mar Ecol Prog Ser 245: 213-221. Link: https://bit.ly/32RuDhB

10. Hsu HY, Chen HW, Han YS (2019) Habitat partition and its possible genetic background between two sympatrically distributed eel species in Taiwan. Zool Stud 58: 27. Link: https://bit.ly/32Uly6n

11. Cott HB (1940) Adaptive coloration in animals. London, Methuen \& Co. Link: https://bit.ly/2Z3CVlv

12. Felsenstein J (1985) Confidence limits on phylogenies: An approach using the bootstrap. Evolution 39: 783-791. Link: https://bit.ly/2EVUSeT

13. Tamura K, Nei M, Kumar S (2004) Prospects for inferring very large phylogenies by using the neighbor-joining method. Proceedings of the National Academy of Sciences (USA) 101: 11030-11035. Link: https://bit.ly/34ZD1hz

14. Kumar S, Stecher G, Li M, Knyaz C, Tamura K (2018) MEGA X: Molecula Evolutionary Genetics Analysis across computing platforms. Molecular Biology and Evolution 35: 1547-1549. Link: https://bit.ly/31UdrJe

15. Chino N, Arai T (2010) Habitat use and habitat transitions in the tropical eel, Anguilla bicolor bicolor. Environ Biol Fish 89: 571-578. Link: https://bit.ly/2QTd2jy

16. Nguyen AT, Tsukamoto K, Lokman PM (2018) Composition and distribution of freshwater eels Anguilla spp. in Vietnam. Fish Sci 84: 987-994. Link: https://bit.ly/2Dpz6PP

17. Menon NG, Balachandran K, Scariah KS (1998) The eels and eel fisheries of India. Mar Fish Inf Serv Tech Ext Ser 157:10-14. Link: https://bit.ly/3574Gx4

18. Bell-Cross G, Minshull JL (1988) The fishes of Zimbabwe. National Museums and Monuments of Zimbabwe, Harare, Zimbabwe. Link: https://bit.ly/32UihoS

19. Okeyo DO (1998) Updating names, distribution and ecology of riverine fish of Kenya in the Athi-Galana-Sabaki river drainage system. Naga, the ICLARM Quarterly 21: 44-53. Link: https://bit.ly/2Z1qsi8 
20. Watanabe S, Aoyama J, Tsukamoto K (2006) Confirmation of morphological differences between Anguilla australis australis and A. australis schmidtii. N Z Journal Mar Freshwater Res 40: 325-331. Link: https://bit.ly/2QP2r9v

21. Jacoby D, Gollock M (2014) Anguilla interioris The IUCN Red List of Threatened Species 2014.

22. Sugeha HY, Suharti SR, Wouthuyzen S, Sumadhiharga K (2008) Biodiversity, distribution and abundance of the tropical anguillid eels in the Indonesian waters. Mar Res Indonesia 33: 129-138. Link: https://bit.ly/3jFFLVx

23. Shirotori F, Ishikawa T, Tanaka C, Aoyama J, Shinoda A, Yambot AV Yoshinaga T (2016) Species composition of anguillid glass eels recruited at southern Mindanao Island, the Philippines. Fish Sci 82: 915-922. Link: https://bit.ly/3jHUuzq

24. Aoyama J, Watanabe S, Ishikawa S, Nishida M, Tsukamoto K (2000) Are morphological characters distinctive enough to discriminate between two species of freshwater eels, Anguilla celebesensis and A. interioris? Ichthyol Res 47: 157-161. Link: https://bit.ly/2Z1408F

25. Hagihara S, Aoyama J, Limbong D, Tsukamoto K (2012) Morphological and physiological changes of female tropical eels, Anguilla celebesensis and Anguilla marmorata, in relation to downstream migration. J Fish Biol 81:408426. Link: https://bit.ly/3hVEbOO

26. Arai T, Miller MJ, Tsukamoto $\mathrm{K}$ (2003) Larval duration of the tropical eel Anguilla celebesensis from Indonesian and Philippine coasts. Mar Ecol Prog Ser 251: 255-261. Link: https://bit.ly/3IMGwhh

27. Marquet G, Galzin R (1991) The eels of French Polynesia: taxonomy, distribution and biomass. La Mer 29: 8-17.

28. Jacoby D, Gollock M (2014) Anguilla megastoma The IUCN Red List of Threatened Species 2014.

29. Shiao JC, Tzeng WN, Collins A, lizuka Y (2002) Role of marine larval duration and growth rate of glass eels in determining the distribution of Anguilla reinhardtii and $A$. australis on Australian eastern coasts. Mar Freshwater Res 53: 687-695. Link: https://bit.ly/32WeuHC

30. Merrick JR, Schmida GE (1984) Australian freshwater fishes: biology and management, Vol. Griffin Press Ltd., South Australia

31. Lin YJ, Jessop BM, Weyl OLF, lizuka Y, Lin SH, et al. (2012) Regional variation in otolith Sr:Ca ratios of African longfinned eel Anguilla mossambica and mottled eel Anguilla marmorata: a challenge to the classic tool for reconstructing migratory histories of fishes. J Fish Biol 81: 427-441. Link: https://bit.ly/2ESoERI

32. Tsukamoto K, Nakai I, Tesch WV (1998) Do all freshwater eels migrate? Nature 396: 635-636. Link: https://go.nature.com/354deVB

33. Kottelat M, Whitten AJ, Kartikasari SN, Wirjoatmodjo S (1993) Freshwater fishes of western Indonesia and Sulawesi. Periplus Editions, Hong Kong, 221. Link: https://bit.ly/3IMr9FS

34. Martin-Smith KM, Hui TH (1998) Diversity of freshwater fishes from eastern Sabah: Annotated checklist for Danum Valley and a consideration of inter- and intra-catchment variability. Raff Bull Zool 46: 573-604. Link: https://bit.ly/3hUSiEd

35. Resh VH, Moser M, Poole M (1999) Feeding habits of some freshwater fishes in streams of Moorea, French Polynesia. Ann Limnol Int Journal Lim 35: 205 210. Link: https://bit.ly/31Tn4aU

36. Watanabe S, Miller MJ, Aoyama J, Tsukamoto K (2011) Analysis of vertebral counts of the tropical anguillids, Anguilla megastoma, A. obscura, and A. reinhardtii, in the western South Pacific in relation to their possible population structure and phylogeny. Environ Biol Fish 91: 353-360. Link: https://bit.ly/3bkn1bl
37. McDowall RM (1990) New Zealand freshwater fishes: a natural history and guide. Hene-mann Reed MAF Publishing Group, Auckland/Wellington. Link: https://bit.ly/3blnNom

38. Jellyman DJ, Bonnett ML, Sykes JR, Johnstone P (2003) In: Dixon DA (ed) Biology, Management, and Protection of Catadromous Eels. American Fisheries Society Symposium 33, Bethesda, Maryland, USA, pp. 63-78. Link: https://bit.ly/33bPyMm

39. Jessop BM, Cairns DK, Thibault I, Tzeng WN (2008) Life history of American eel Anguilla rostrata: new insights from otolith microchemistry. Aquatic Biol 1 : 205-216. Link: https://bit.ly/2YZ4o7C

40. Jacoby D, Gollock M (2014) Anguilla anguilla The IUCN Red List of Threatened Species 2014.

41. Irion U, Nüsslein-Volhard C (2019) The identification of genes involved in the evolution of color patterns in fish. Curr Opin Genet Dev 57: 31-38. Link: https://bit.ly/2F0Ax7X

42. Pankhurst NW, Lythgoe JN (1982) Structure and colour of the integument of the European eel Anguilla anguilla (L.). J Fish Biol 21: 279-296. Link: https://bit.ly/2QQyp5a

43. Stuart-Fox D, Moussalli A (2009) Camouflage, communication, and thermoregulation: lessons from colour changing organisms. Philos Trans Royal Soc B Biol Sci 364: 463-470. Link: https://bit.ly/3INXk7F

44. Hanlon R (2007) Cephalopod dynamic camouflage. Curr Biol 17: R400-R404. Link: https://bit.ly/2EX3NfQ

45. Hamilton WJ, Peterman RM (1971) Countershading in colourful reef fish Chaetodon lunula: Concealment, communication or both? Anim Behav 19 357-364. Link: https://bit.ly/31U16V7

46. Cuthill IC, Sanghera NS, Penacchio O, Lovell PG, Ruxton GD, et al. (2016) Optimizing countershading camouflage. Proc Natl Acad Sci U S A 113: 1309313097. Link: https://bit.ly/3gTK3qK

47. Newson MD (1994) Hydrology and the river environment, Vol. Oxford University Press, U.S.A.

48. Han YS, Lin YF, Wu CR, lizuka Y, Castillo TR, et al. (2016) Biogeographic distribution of the eel Anguilla luzonensis: dependence upon larval duration and oceanic currents. Mar Ecol Prog Ser 551: 227-238. Link: https://bit.ly/2EL3vJj

49. Barth JMI, Gubili C, Matschiner M, Tørresen OK, Watanabe S, et al. (2020) Stable Species Boundaries Despite Ten Million Years of Hybridization in Tropical Eels. Nat Comm 11:1433. Link: https://bit.ly/3IF0avT

50. Arai T, Chino N (2018) Opportunistic migration and habitat use of the giant mottled eel Anguilla marmorata (Teleostei: Elopomorpha). Sci Rep 8: 5666 Link: https://go.nature.com/31Q00le

51. Arai T, Wong LL (2015) Validation of the occurrence of the tropical eels, Anguilla bengalensis bengalensis and A. bicolor bicolor at Langkaw Island in Peninsular Malaysia, Malaysia. Trop Ecol 57: 23-31. Link: https://bit.ly/2Z3egxh

52. Saitou N, Nei M (1987) The neighbor-joining method: A new method for reconstructing phylogenetic trees. Molecular Biology and Evolution 4: 406425. Link: https://bit.ly/3jTr41t

53. Tzeng WN, Hsiao JJ, Shen HP, Chern YT, Wang YT, et al. (1995) Feeding habit of the Japanese eel Anguilla japonica in the streams of northern Taiwan. $J$ Fish Soc Taiw 22: 279-302.

54. Watanabe S, Aoyama J, Tsukamoto K (2009) A new species of freshwate eel Anguilla luzonensis (Teleostei: Anguillidae) from Luzon Island of the Philippines. Fish Sci 75: 387-392. Link: https://bit.ly/2F3mVIN

Copyright: (C) 2020 Hsu HY, et al. This is an open-access article distributed under the terms of the Creative Commons Attribution License, which permits unrestricted use, distribution, and reproduction in any medium, provided the original author and source are credited. 